\title{
Analisis Pengaruh Product Assortment dan Desain Kemasan Terhadap Minat Beli Pada UMKM Di Kota Bima
}

\author{
Iryanti Wahyuni ${ }^{1}$, Sri Ernawati ${ }^{2}$ \\ ${ }^{1,2}$ Sekolah Tinggi Ilmu Ekonomi Bima \\ Email: ${ }^{1}$ iryantiwahyuni.stiebima16@gmail.com, ${ }^{2}$ sriernawati.stiebima@gmail.com

\begin{tabular}{ccc}
\hline Diterima & Direvisi & Disetujui \\
$22-02-2020$ & $26-02-2020$ & $03-03-2020$ \\
\hline
\end{tabular}

\begin{abstract}
Abstrak - Kegiatan Usaha Mikro, Kecil, dan Menengah (UMKM) merupakan salah satu bidang usaha yang dapat berkembang dan konsisten dalam perekonomian suatu negara ataupun daerah. Penelitian ini bertujuan untuk menguji pengaruh product assortment dan desain kemasan terhadap minat beli pada UMKM di Kota Bima. Penelitian ini menggunakan desain penelitian survei pada responden dengan menyebarkan kuesioner kepada konsumen pada UMKM di Kota Bima.Populasi penelitian ini adalah konsumen UMKM di Kota Bima yang jumlahnya tidak bisa diukur dengan pasti (unknown population). Sampel dalam penelitian ini berjumlah 50 responden menggunakan teknik purposive sampling.Teknik pengumpulan data menggunakan kuesioner dengan skala Likert, yang masing-masing telah diuji dan telah memenuhi persyaratan validitas dan reliabilitas.Analisis data menggunakan regresi linier berganda dan pengujian hipotesis menggunakan uji signifikansi parsial (uji t). Hasil analisis regresi linier berganda dengan SPSS versi 20 menunjukan bahwa product assortment tidak mempunyai pengaruh positif dan signifikan terhadap minat beli pada UMKM di Kota Bima, dan desain kemasan mempunyai pengaruh positif dan signifikan terhadap minat beli pada UMKM di Kota Bima.
\end{abstract}

Kata Kunci : Product Assortment, Desain Kemasan, dan Minat Beli

\begin{abstract}
Micro Business Activities, Small and Medium Enterprises (UMKM) is one of the business sectors that can develop and be consistent in the economy of a country or region. This study aims to examine the effect of product assortment and packaging design on buying interest in UMKM in the Bima City. his study uses survey research design on respondents by distributing questionnaires to consumers at UMKM in the Bima City. The population of this study is UMKM consumers in the Bima City whose numbers cannot be measured with certainty (unknown population). The sample in this study amounted to 50 respondents using purposive techniques sampling. Data collection techniques using a questionnaire with a Likert scale, each of which has been tested and has met the requirements of validity and reliability. Data analysis using multiple linear regression and hypothesis testing using partial significance test ( $t$ test). The results of multiple linear regression analysis with SPSS version 20 show that product assortment has no positive and significant influence on buying interest in UMKM in Bima City, and packaging design has a positive and significant effect on buying interest in UMKM in Bima City
\end{abstract}

Keywords : product assortment, packaging designand buying interest

\section{PENDAHULUAN}

Arus globalisasi perdagangan internasional adalah fenomena yang menerjang hampir seluruh negara. Derasnya arus globalisasi aktif dalam pengembangan ekonomi negaranegara berkembang berakibat pada persaingan di sektor industri. Usaha Mikro Kecil dan Menengah ialah satu diantara usaha di Indonesia yang mampu memberikan kontribusi cukup besar dan memiliki potensi berkompetesi di pasar Internasional. UMKM mempunyai peranan penting dan strategis dalam pembangunan ekonomi nasional. UMKM juga terbukti tidak terpengaruh terhadap kirisis. Ketika krisis ekonomi melanda tahun 1997-1998, hanya usaha tersebut yang dapat berdiri kokoh.( Utami \& Silaningsih, 2018)

Usaha Mikro, Kecil dan Menengah (UMKM) merupakan memiliki peranan yang sangat penting bagi pemerintahan Kota Bima, karena jumlahnya banyak dan tersebar dimana-mana, serta dapat memberi kesempatan kerja yang potensial. Peranan UMKM tersebut menjadi bagian yang diutamakan dalam setiap perencanaan tahapan pembangunan pemeritah, namun demikian usaha pengembangan yang telah dilaksanakan masih belum memuaskan hasilnya, karena pada kenyataannya kemajuan UMKM sangat kecil dibandingkan dengan kemajuan yang sudah dicapai usaha besar. Padahal, UMKM memiliki banyak hal dalam keunggulan diantaranya 
inovasi dalam pengembangan produk, hubungan kemanusiaan yang akrab, menciptakan kesempatan kerja yang cukup banyak, dan mampu menyesuaikan pasar yang selalu berubah dengan cepat.

Keunggulan-keunggulan inilah yang bisa digunakan untuk mengahadapi persaingan yang semakin ketat, karena semakin terbukannya pasar didalam negeri, merupakan ancaman bagi UMKM dengan semakin banyaknya barang dan jasa yang masuk dari luar dampak globalisasi. Oleh karena itu, pembinaan dan pengembangan UMKM saat ini dirasakan semakin mendesak dan sangat strategis untuk mengangkat perekonomian rakyat, (Sugiyanto et al. 2017). Kemandirian UMKM dapat tercapai dimasa mendatang. Dengan berkembangnya perekonomian rakyat diharapkan dapat meningkatkan pendapatan masyarakat, membuka kesempatan kerja, dan memakmurkan masyarakat secara keseluruhan.( Juniawan et al, 2019)

Keberagaman produk termasuk strategi yang perlu dirumuskan oleh UMKM dalam menarik minat beli.Penting bagi suatu UMKM untuk menyediakan produk yang beranekaragam, hal ini dikarenakan adanya kecenderungan dalam diri konsumen yang menghendaki barang-barang yang beragam, sehingga dengan bermacam-macam produk yang disediakan diharapkan dapat memberikan dorongan dan pilihan bagi konsumen untuk membeli produk yang disediakan oleh suatu UMKM. Persaingan merupakan hal yang harus diperhatikan pusat perbelanjaan untuk terus bertahan terutama dikawasan kota Bandung. Salah satu yang harus diperhatikan adalah keragaman produk, Penyediaan keragaman produk (produk assortment) yang baik tidak hanya akan menarik minat tetapi dapat mempengaruhi keputusan konsumen untuk berbelanja ( Foster, 2015)

Desain produk merupakan salah satu faktor utama yang menjadi pertimbangan konsumen dalam memilih batik karena desain dari suatu produk akan mempengaruhi penampilan, seperti yang dikemukakan oleh Kotler bahwa desain merupakan totalitas keistimewaan yang mempengaruhi penampilan dan fungsi suatu produk dari segi kebutuhan konsumen (Kotler, 2012). Desain kemasan merupakan salah satu strategi perusahaan untuk dapat melakukan persaingan dalam dunia bisnis, selain itu untuk dapat menciptakan citra merek dalam benak konsumen yang bertujuan untuk menarik konsumen sebanyakbanyaknyasehingga konsumen melakukan keputusan pembelian terhadap produk tersebut (Mufreni, 2016)

Kendala yang sering dihadapi oleh pelaku usaha di Kota Bima adalah kurangnya kemampuan dalam membuat desain kemasan produk. Pengetahuan yang rendah mengenai tata cara perancangan dan pembuatan kemasan juga menjadi masalah tersendiri bagi UMKM di Kota Bima, Industri UMKM di Kota Bima saat ini banyak bergerak di bidang makanan dengan desain kemasan yang masih seadanya saja. Dengan adanya masalah ini, berdampak pada nilai jual produk yang rendah, walaupun cita rasa produk layak untuk dihargai tinggi.

\section{Product Assortment}

Menurut (Kotler dan Keller, 2016:402) product assortment yaitu " is the set of all products and items a particular seller offers for sale." Atau seperangkat keseluruhan produk yang ditawarkan untuk dijual oleh penjual tertentu.

Menurut (Kotler \& Keller, 2012:25) keragaman produk adalah tersedianya semua jenis produk mulai dari banyaknya jumlah, kesesuaian dengan selera dan keinginan serta ketersediaan produk yang ditawarkan untuk dimiliki, dipakai atau di konsumsi, oleh konsumen yang dihasilkan oleh suatu produsen.

\section{Desain Kemasan}

Kotler dan Armstrong (2014) mendefinisikan "packaging involves designing and producing the countainer or wrapper for a product" yang artinya adalah proses kemasan melibatkan kegiatan mendesain dan memproduksi, fungsi utama dari kemasan sendiri yaitu untuk melindungi produk agar produk tetap terjaga kualitasnya.

Umumnya, tujuan desain kemasan khusus untuk masing-masing produk atau merek tertentu.Desain kemasan bisa diarahkan untuk menampilkan atribut unik sebuah produk. Memperkuat penampilan estetika dan nilai produk, mempertahankan keseragaman dalam kesatuan merek produk, memperkuat perbedaan antara ragam produk dan lini produk, mengembangkan bentuk kemasan berbeda sesuai dengan kategori, menggunakan material baru dan mengembangkan struktur inovatif untuk mengurangi biaya, lebih ramah lingkungan, atau meningkatkan fungsionalitas. (Klimchuk \& Sandra, 2012)

\section{Minat Beli}

Menurut (Kotler dan Keller, 2016:15) Minat Beli merupakan perilaku yang muncul sebagai respon terhadap objek yang menunjukan keinginan konsumen untuk melakukan pembelian. Minat beli merupakan pernyataan mental dari dari konsumen yang merefleksikan rencana pembelian sejumlah produk dengan merek tertentu. Hal ini sangat diperlukan oleh para pemesar untuk mengetahui minat beli konsumen terhadap suatu produk, baik para pemasar maupun ahli ekonomi menggunakan variabel minat untuk memprediksi perilaku konsumen dimasa yang akan datang ( Susetyarsi, 2013), seperti hasil dimana menunjukkan bahwa product assortment pada The Secret FO ini telah mampu menciptakan minat beli. Dimana mulai dari indikator produk yang ditawarkan beragam, harga yang terjangkau, mer-merk yang ditawarkan sudah terkenal dan jajaran produk yang ditawarkan 
lengkap telah mampu memberikan minat beli.(Girsang \&widodo, 2014)

Tabel 1. Dimensi Variabel Product Assortment, Desain Kemasan, dan Minat Beli

\begin{tabular}{|l|l|l|}
\hline \multirow{2}{*}{ Variabel X } & $\begin{array}{l}\text { Product } \\
\text { Assortment }\end{array}$ & $\begin{array}{l}\text { Lebar bauran produk, } \\
\text { panjang bauran produk, } \\
\text { kedalaman bauran } \\
\text { produk, dan konsistensi } \\
\text { dari bauran produk }\end{array}$ \\
\cline { 2 - 4 } & $\begin{array}{l}\text { Desain } \\
\text { Kemasan }\end{array}$ & $\begin{array}{l}\text { Bentuk kemasan, } \\
\text { ukuran kemasan sesuai } \\
\text { keinginan, kemasan } \\
\text { simple dan praktis }\end{array}$ \\
\hline Variabel Y & Minat Beli & $\begin{array}{l}\text { Minat transaksional, } \\
\text { minat referensial, minat } \\
\text { preferensial, minat } \\
\text { eksploratif }\end{array}$ \\
\hline
\end{tabular}

\section{METODE PENELITIAN}

Penelitian ini menggunakan pendekatan kuantitatif dengan metode survey.Menurut (Hartono, 2010) survei adalah metode pengumpulan data primer dengan memberikan pertanyaan-pertanyaan kepada responden individu.Kuesioner digunakan untuk mengumpulkan data dari responden yang merupakan konsumen dari UMKM di Kota Bima.

Populasi dalam penelitian ini adalah konsumen UMKM di Kota Bima Teknik pengambilan sampel yang digunakan dalam penelitian ini adalah purposive sampling yaitu teknik pengambilan sampel dari populasi berdasarkan kriteria tertentu Hartono, 2010). Jumlah sampel dalam yang diambil dalam penelitian ini adalah 50 responden (Amirullah, 2013), dengan kriteria orang yang pernah membeli produk UMKM Kota Bima khususnya produk makanan dan minuman dan usia diatas 17 tahun karena dianggap mampu menjawab pernyataan dari kuesioner.

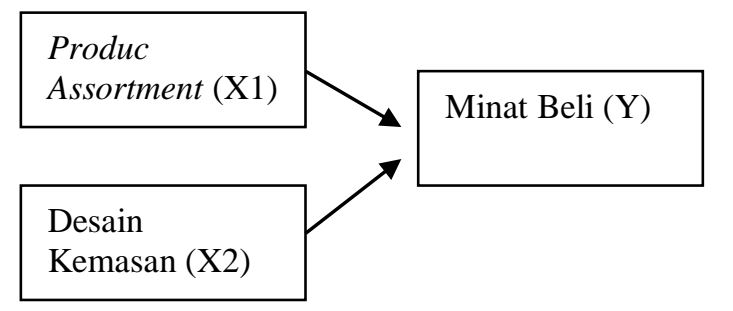

Keterangan :

$\longrightarrow$ :Pengaruh secara parsial

$\mathrm{H}_{1}$ :Product assortment tidak berpengaruh secara positif terhadap minat beli

$\mathrm{H}_{2}$ : Desain kemasan berpengaruh secara positif terhadap minat beli

\section{HASIL DAN PEMBAHASAN}

\section{a. Analisis Regresi Linier Berganda}

Pengujian hipotesis dalam penelitian ini menggunakan analisis regresi linier berganda dengan bantuan program SPSS 20.00 for Windows untuk mengetahui pengaruh variabel product assortment $\left(\mathrm{X}_{1}\right)$, dan desain kemasan $\left(\mathrm{X}_{2}\right)$ terhadap minat beli (Y) secara parsial. Hasil uji regresi linier berganda dalam penelitian ini dapat dilihat pada tabel berikut:

Tabel 2

Hasil Uji Regresi Linier Berganda

\begin{tabular}{|l|r|l|l|}
\hline Variabel & $\begin{array}{l}\text { Standardi } \\
\text { zed } \\
\text { Coefficien } \\
\text { ts Beta }\end{array}$ & Sig & Keterangan \\
\hline $\begin{array}{l}\text { Product } \\
\text { Assortmen } \\
t\end{array}$ & -.172 & .401 & $\begin{array}{l}\text { Negatif dan } \\
\text { tidak } \\
\text { signifikan }\end{array}$ \\
\hline $\begin{array}{l}\text { Desain } \\
\text { Kemasan }\end{array}$ & .557 & .000 & $\begin{array}{l}\text { Positif dan } \\
\text { signifikan }\end{array}$ \\
\hline
\end{tabular}

Sumber: Data Primer, 2020

Berdasarkan hasil uji regresi linier berganda pada table 1, dapat ditulis dari hasil pengujian tersebut sebagai berikut:

$$
Y=-\mathbf{0 , 1 7 2}\left(X_{1}\right)+\mathbf{0 , 5 5 7}\left(X_{2}\right)
$$

Persamaan diatas dapat dijelaskan sebagai berikut:

1) Standardized Coeffiecients Beta dari variabel product assortment sebesar -0,172 dan bertanda negatif, artinya variabel product assortment tidak mempunyai pengaruh positif sebesar $-0,172$ terhadap minat beli

2) Standardized Coefficients Beta dari vaiabel desain kemasan sebesar 0,557 dan bertanda positif, artinya variabel desain kemasan mempunyai pengaruh positif sebesar 0,557 terhadap minat beli. Hal ini menunjukan bahwa semakin menarik desain kemasan suatu produk maka akan meningkatkan minat beli konsumen pada UMKM di Kota Bima.

\section{b. Uji Signifikansi}

Uji signifikansi dimaksudkan untuk mengetahui seberapa jauh pengaruh satu variabel product assortment $\left(\mathrm{X}_{1}\right)$ dan desain kemasan $\left(\mathrm{X}_{2}\right)$ terhadap variabel minat beli (Y) secara parsial.Hasil uji t pada penelitian ini dapat dilihat pada tabel 1 , diketahui bahwa pengaruh product assortment $\left(\mathrm{X}_{1}\right)$ terhadap minat beli (Y) menunjukan nilai tidak signifikansi sebesar 0,401. Variabel desain kemasan $\left(\mathrm{X}_{2}\right)$ terhadap minat beli (Y) menunjukan nilai signifikansi sebesar 0,00. Variabel desain kemasan $\left(\mathrm{X}_{2}\right)$ mempunyai nilai signifikansi t lebih kecil dari taraf $5 \%(<0,05)$. Hasil ini menunjukan bahwa 
variabel desain kemasan $\left(\mathrm{X}_{2}\right)$ berpengaruh positif dan signifikan terhadap minat beli.

\section{Hasil Uji Hipotesis}

Tabel 3. Hasil Uji Hipotesis

\begin{tabular}{|l|r|l|l|}
\hline Variabel & t-hit & t-tab & Keterangan \\
\hline $\begin{array}{l}\text { Produc } \\
\text { Assortment }\end{array}$ & -.847 & 1,6765 & $\begin{array}{c}\text { Tidak } \\
\text { Berpengaruh }\end{array}$ \\
\hline $\begin{array}{l}\text { Desain } \\
\text { Kemasan }\end{array}$ & 4.144 & 1,6765 & Berpengaruh \\
\hline
\end{tabular}

Sumber: Data Primer, 2020

\section{a. Pengaruh product assortment terhadap minat beli}

Berdasarkan tabel 1 hasil analisis regresi linier berganda menunjukan bahwa variabel product assortment memiliki nilai t hitung $-0,847$ dan $\mathrm{t}$ tabel $1,6765(-0,847<1,6765)$ dengan signifikansi tersebut lebih besar dari taraf $5 \%(0,401>0,05)$. sehingga hipotesis hasil penelitian yang menunjukan bahwa variabel product assortment tidak berpengaruh positif dan tidak signifikan terhadap minat beli konsumen "di terima". Hasil penelitian ini berbeda dengan hasil penelitian (Girsang \& widodo,2014) yang menyatakan product assortment berpengaruh terhadap minat beli pada The Secret factory outlet Bandung

Dengan demikian dapat disimpulkan konsumen tidak memiliki sikap positif terhadap UMKM di Kota Bima sehingga minat beli menurun. Penyediaan keragaman produk (produk assortment) yang baik tidak hanya akan menarik minat tetapi dapat mempengaruhi keputusan konsumen untuk berbelanja untuk itu UKMK Kota Bima harus selalu melakukan inovasi produk agar minat beli konsumen meningkat.

\section{b. Pengaruh desain kemasan terhadap minat beli}

Berdasarkan tabel 1 hasil analisis regresi linier berganda menunjukan bahwa variabel desain kemasan memiliki nilai $t$ hitung 4,144 dan t tabel $1,6765(4,144>1,6765$ dengan nilai signifikan sebesar 0,00. Nilai signifikansi tersebut lebih kecil dari taraf $5 \%(0,00<0,05)$. sehingga hipotesis hasil penelitian yang menunjukan bahwa variabel desain kemasan berpengaruh positif dan signifikan terhadap minat beli konsumen "diterima". Hasil penelitian ini sama dengan hasil penelitian. (Mufreni, 2016) yang menyatakan bahwa Desain kemasan dapat memepengaruhi dan meningkatkan minat pembelian konsumen (Studi kasus the hijau serbuk Tocha)

Dengan demikian dapat disimpulkan konsumen memiliki sikap positif terhadap UMKM di Kota Bima sehingga minat beli meningkat. Dalam penelitian ini konsumen mempresepsikan bahwa UMKM di Kota Bima mempunyai desain kemasan yang menarik sehingga dapat meningkatkan minat beli konsumen.

\section{KESIMPULAN}

Berdasarkan hasil penelitian dan pembahasan dalam penelitian ini, menyatakan bahwa minat beli yang ditimbulkan dari UMKM di Kota Bima dipersepsikan belum baik oleh responden, sehingga pihak UMKM di Kota Bima harus fokus untuk selalu meningkatkan product assortment karena banyak konsumen yang belum tertarik dengan product assortment UMKM Kota Bima, perlunya inovasi produk sehingga tercipta minat beli pada produk UMKM.

Variabel desain kemasan dipersepsikan baik oleh responden, sehingga pihak UMKM di Kota Bima harus fokus untuk mempertahankan dan meningkatkan konsep desain kemasan yang telah ada hingga menyentuh sisi emosional konsumen, yang berdampak konsumen akan senantiasa membeli produk UMKM di Kota Bima. Desain kemasan yang ada pada produk UMKM di Kota Bima sudah mampu menciptakan kesan positif pada diri konsumen sehingga manfaat yang diharapkan mampu secara lebih besar dirasakan oleh konsumen.

\section{REFERENSI}

Amirullah. (2013). Metodologi Penelitian Manajemen. Malang: Bayumedia.

Foster Bob, 2015. Pengaruh Product Assortment dan Gaya Hidup Hedonis Terhadap Impulse Buying Pengunjung Trans Studio Mall (TSM) Bandung. Sosiohumaniora, Volume 17 No. 1 Hal: $56-59$

Fure, Hendra. 2013. Lokasi, Keberagaman Produk, Harga dan Kualitas Pelayanan Pengaruhnya Terhadap Minat Beli pada Pasar Tradisional Bersehari Calaca. Jurnal EMBA, 1(3), 273283.

Girsang Julianti Putri \& Widodo Arry, 2014. Pengaruh Store Atmosphere Dan Product Assortment Terhadap Minat Beli Pada The Secret Factory Outlet Bandung . IMAGE (Jurnal Riset Manajemen). Vol No 1

Hartono, Jogiyanto. (2010). Metodologi Penelitian Bisnis: Salah Kaprah dan PengalamanPengalaman. Edisi Pertama. BPFE. Yogyakarta

Juniawan Fransiskus, Sujono, Hamidah \& Sylfania, 2019. Pelatihan Desain Kemasan Bagi UKM Rumah Tangga di Bangka Barat. Seminar Nasional Hasil Pengabdian Kepada 
Masyarakat 2019 SINDIMAS 2019 STMIK Pontianak, 29 Juli 2019

Klimchuck, Marianne R., \& Krasovec, Sandra A. 2012. Packaging Design: Successful Product Branding from Concept to Shelf, Second edition. New Jersey: Wiley

Kotler, Philip and Kevin Lane Keller, 2012. Marketing Management, Edisi 14, New Jersey: Prentice-Hall Published. Kotler, Philip and Kevin

Lane Keller, 2016. Marketing Managemen, 15th Edition, Pearson Education,Inc.

Kotler, Philip \& Gerry Armstrong, (2014): Principle Of Marketing, 15th edition. New Jersey: Pearson Pretice Hall.

Mufreni, 2016. Pengaruh desain produk, bentuk kemasan dan bahan kemasan terhadap minat beli konsumen (Studi kasus the hijau serbuk tocha)Jurnal Ekonomi Manajemen Vol 2 No 2 Hal 48-54
Sugiyanto, Karima Aisyatul \& Yogananti F Auria, 2017. Peningkatan Ketrampilan Pembuatan Desain Kemasan serta Pemanfaatan Media Promosi dan Pemasaran Online Pada Kube Ash-Shidiqqy dan Pik Abdussalam Jepara. Tecno.Com Vol 16 No 1 Hal 9-16

Susetyarsi . 2013. Analisis Pengaruh Strategi Desain Produk Terhadap Minat Beli Konsumen Pada Skuter Matik Yamaha Merek Mio Fino di Kota Semarang. Jurnal Stie Semarang, VOL 5, NO 1. ISSN : 2252-7826

Utami P \& Silaningsih E, 2018 . Pengaruh Marketing Mix Terhadap Minat Beli Konsumen Pada Usaha Mikro Kecil dan Menengah (UMKM) Produk Olahan Makanan Ringan. Jurnal Sosial Humaniora Vol 9 No 2 Hal: 144-158. 